\title{
The Sea as a Source of Antibiotics
}

\section{Sara M Soto*}

Barcelona Institute for Global Health (ISGlobal), Edificio CEK-1ª planta; C/Rosselló 149-153, 08036-Barcelona, Spain

*Corresponding author: Sara M Soto, Barcelona Institute for Global Health (ISGlobal), Edificio CEK-1ª planta; C/ Rosselló 149-153, 08036-Barcelona, Spain, Tel: +34-932275707; Fax: +34-932279327; E-mail: sara.soto@isglobal.org

Received date: August 12, 2015; Accepted date: August 13, 2015; Published date: August 20, 2015

Copyright: (C) 2015 Soto SM, et al. This is an open-access article distributed under the terms of the Creative Commons Attribution License, which permits unrestricted use, distribution, and reproduction in any medium, provided the original author and source are credited.

\section{Description}

Over the past few decades, there has been a decline in antibiotics development, resulting in fewer new antimicrobial agents approvals. Thus, the era of antibiotics began in the 1920s and 30s with the discovery of penicillin by Alexander Fleming. There are now over 13 classes of antibiotics, some into their fifth generation, consisting on synthetic derivatives from older antibiotics and natural compounds. In the first decades, about 15-20 new antibiotics were developed each decade, but in the last ten years only 6 new drugs have come on the market. In addition to the scarce development of antibiotics, the emergence and increase of multiresistant bacteria to the existent antibiotics used in clinical practice are limiting treatment options for patients.

For these reasons, a need of finding new molecules with antimicrobial activity exists.

Nature is an enormous source of biodiversity that could provide us with new molecules from plants, fungi, and other macro- and microorganisms. In this aspect, seas and oceans are being investigated.

Nowadays, two millions of marine species are known and about 10,000 new species are discovered each year. It is estimated that about 100 millions of species could form part of our seas and oceans.

The potential of the oceans has been discovered by the pharmaceutical/biological research trying to obtain from their habitants some chemical substances, known as active principles that could have effects against pathogenic microorganisms and/or other medical utilities. Nowadays, molecules obtained from marine species have been used against malaria, HIV, or cancer, among others clinical problems.

Among the marine organisms, microalgae are being the focus of the research for new antimicrobial agents.

Microalgae biodiversity is very high, with more than 3,000 known prokaryotic taxons and more than 30,000 eukaryotic species identified among databases $[1,2]$. This huge biodiversity involves also great ecologic diversities, with microalgae species adapted for growing conditions in all types of waters (salty, brackish, fresh), and temperatures (ranging from polar to tropical and even extremely hot conditions) [3,4]. They are also adapted to diverse light intensities (surface waters, symbiosis inside animals and deep waters) [5], and are able to survive at large $\mathrm{pH}$ ranges [6]. Microalgae metabolism can be autotrophic, heterotrophic or even mixotrophic [7,8]. All metabolic possibilities are consequently associated to these taxonomic and ecologic diversities. All these genetic copiousness is also responsible for the existence, in most microalgae, of complex biosynthetic pathways. These pathways give rise to a vast array of enzymes and metabolites that have attracted industry attention [9].
As other photosynthetic cells, microalgae produce a diverse array of profitable, often unexplored products, with applications in the pharmacy, food, feed, cosmetic and chemistry sectors. Some of these compounds already possess a market price that makes their production at industrial scale highly profitable.

Some important examples of these products from microalgae are polyunsaturated fatty acids (PUFAs as $\omega-3$ and $\omega-6$ ) with cardioprotective and anti-inflammatory effects against different types of cancers (in the case of $\omega-3$ ). Vitamins (E, C) are important antioxidants in animal nutrition, protecting different tissues and organs from damage caused by reactive oxygen species (ROS) as in atherosclerosis or neuron damage [10-12]. Bio-colorants as phycocyanin, beta-carotene, astaxanthin and lutein are used as natural colorants in food or feed, with an important antioxidant effect on prevention of diseases (vitamin A blindness, macular degeneration) $[13,14]$. Immunostimulants and hypolipidemic-glucides as $\beta-1,3-$ glucan are polysaccharides showing antitumor activity and antiatherosclerosis effects $[15,16]$. Cell extracts from several microalgae species have demonstrated in vitro antimicrobial activity against several bacterial and fungal pathogens and an inhibitory effect on the growth of various human tumor cell lines [17]. Aquaculture feed is used in the intensive farms of salmon, shrimps, bivalves, etc., where some microalgae species provide a high protein and/or a $\omega-3$ fatty acids content [18]. Cosmetic ingredients exert an intense antioxidant activity and a diverse array of functions on epithelial cellular processes (lipases inhibition, aquaporins induction) $[19,20]$. Industrial enzymes (lipases, cellulases or proteases) sometimes are used under high temperatures or extreme $\mathrm{pH}$ conditions, where conventional enzymes cannot work.

Algae, sponges, corals, jellyfish, echinoderms, sea squirts, sea snails, cephalopods, crustaceans, amphibians, are other marine organisms of which biomolecules with clinical activity have been obtained.

Despite the successes achieved so far, from each 10,000 substances extracted from marine creatures only 100 are bioactive and could be used in clinical.

Although it is well known that seas and oceans are sources of possible molecules with antibacterial activity, further research are needed to find them.

\section{Acknowledgements}

This manuscript was funded by the European Union's Horizon 2020 research and innovation programme under NOMORFILM project (grant agreement No 634588), www.nomorfilm.eu. 


\section{References}

1. Bouchet $P$ (2006) The magnitude of marine biodiversity. In: Duarte CM (ed.) The exploration of marine biodiversity. Scientific and Technological Challenges, France.

2. Appeltans W, Ahyong ST, Anderson G, Angel MV, Artois T, et al. (2012) The magnitude of global marine species diversity. Curr Biol 22: 2189-2202.

3. Guerrero F, Sedoud A, Kirilovsky D, Rutherford AW, Ortega JM, et al. (2011) A high redox potential form of cytochrome c550 in photosystem II from Thermosynechococcus elongatus. J Biol Chem 286: 5985-5994.

4. Remias D, Karsten U, Lütz C, Leya T (2010) Physiological and morphological processes in the Alpine snow alga Chloromonas nivalis (Chlorophyceae) during cyst formation. Protoplasma 243: 73-86.

5. Cooper TF, Lai M, Ulstrup KE, Saunders SM, Flematti GR, et al. (2011) Symbiodinium genotypic and environmental controls on lipids in reef building corals. PLoS One 6: e20434.

6. Matsudo MC, Bezerra RP, Sato S, Converti A, de Carvalho JC (2012) Photosynthetic efficiency and rate of $\mathrm{CO} 2$ assimilation by Arthrospira (Spirulina) platensis continuously cultivated in a tubular photobioreactor. Biotechnol J 7: 1412-1417.

7. Choix FJ, de-Bashan LE, Bashan Y (2012) Enhanced accumulation of starch and total carbohydrates in alginate-immobilized Chlorella spp. induced by Azospirillum brasilense: II. Heterotrophic conditions. Enzyme Microb Technol 51: 300-309.

8. Ratha SK, Babu S, Renuka N, Prasanna R, Prasad RB, et al. (2012) Exploring nutritional modes of cultivation for enhancing lipid accumulation in microalgae. J Basic Microbiol 53: 440-450.

9. de la Noue J, de Pauw N (1988) The potential of microalgal biotechnology: a review of production and uses of microalgae. Biotechnol Adv 6: 725-770.

10. Frank J, Budek A, Lundh T, Parker RS, Swanson JE, et al. (2006) Dietary flavonoids with a catechol structure increase alpha-tocopherol in rats and protect the vitamin from oxidation in vitro. J Lipid Res 47: 2718-2725.
11. Maruyama J, Miller JM, Ulfendahl M (2008) Glial cell line-derived neurotrophic factor and antioxidants preserve the electrical responsiveness of the spiral ganglion neurons after experimentally induced deafness. Neurobiol Dis 29: 14-21.

12. Ozkanlar S, Akcay F (2012) Antioxidant vitamins in atherosclerosis-animal experiments and clinical studies. Adv Clin Exp Med 21: 115-123.

13. Aslam T, Delcourt C, Silva R, Holz FG, Leys A, et al. (2012) Micronutrients in age-related macular degeneration. Ophthalmologica 229: 75-79.

14. Bell JG, McEvoy J, Tocher DR, Sargent JR (2000) Depletion of alphatocopherol and astaxanthin in Atlantic salmon (Salmo salar) affects autoxidative defense and fatty acid metabolism. J Nutr 130: 1800-1808.

15. Harada K, Itashiki Y, Takenawa T, Ueyama Y (2010) Effects of lentinan alone and in combination with fluoropyrimidine anticancer agent on growth of human oral squamous cell carcinoma in vitro and in vivo. Int J Oncol 37: 623-631.

16. Andersson KE, Svedberg KA, Lindholm MW, Oste R, Hellstrand P (2010) Oats (Avena sativa) reduce atherogenesis in LDL-receptor-deficient mice. Atherosclerosis 212: 93-99.

17. Mendiola JA, Santoyo S, Cifuentes A, Reglero G, Ibáñez E, et al. (2008) Antimicrobial activity of sub- and supercritical CO2 extracts of the green alga Dunaliella salina. J Food Prot 71: 2138-2143.

18. Adarme-Vega TC, Lim DK, Timmins M, Vernen F, Li Y, et al. (2012) Microalgal biofactories: a promising approach towards sustainable omega-3 fatty acid production. Microb Cell Fact 11: 96.

19. Buono S, Langellotti AL, Martello A, Bimonte M, Tito A, et al. (2012) Biological activities of dermatological interest by the water extract of the microalga Botryococcus braunii. Arch Dermatol Res 304: 755-764.

20. Tominaga K, Hongo N, Karato M, Yamashita E (2012) Cosmetic benefits of astaxanthin on humans subjects. Acta Biochim Pol 59: 43-47. 